\title{
NUMERICAL MODELING FOR SOIL WATER MOVEMENT UNDER DEFICIT IRRIGATION AND PARTIAL ROOT ZONE DRYING.
}

\author{
Abousrie A. Farag*
}

ABSTRACT

The successful water management is considered one of the best solutions for the problem of water shortage. The first step in successful water management is to estimate the water requirements for crops accurately and monitoring the residual water content in soil during the growth season, but that cost a lot of everts and money. Others most important techniques for water saving are deficit irrigation (DI), partial root zone drying (PRD) and the integration between them. So, the aim of this study is to simulate the water flow in soil by Hydraus-1D as an easy and a cheap method. Also, studying the applied full irrigation (FI), two levels of sustainable deficit irrigation (DI) applied $75 \%$ of total crop evapotranspiration (ETc) (DI75\%) and applied $50 \%$ of ETc (DI $50 \%)$, partial root zone drying (PRD) and the integration between DI and PRD on eggplant yield and water productivity efficiency (WP). The experimental work was carried out during the summer seasons of 2017 and 2018 at the experimental farm of Faculty of Agriculture (Moshtohor), Benha University. The soil water content ( $\theta)$ was measured several times during the growth season by using soil moisture sensor (ML3 Theta Probe) at depths of 10, 30 and $50 \mathrm{~cm}$. In addition, a numerical modeling was used for predicting the soil water content and comparing the output of model with the actual measured soil water content. The results of the numerical model showed that, the simulated and measured $\theta$ values were very close to each other. Moreover, the soil water content under subsurface drip irrigation (SSDI) at a depth of $10 \mathrm{~cm}$ were higher by $15.44 \%$ than the corresponding ones under surface drip irrigation (SDI), while at depths of 30 and $50 \mathrm{~cm}$, the values of $\theta$ under SDI were higher by $7.16 \%$ and $11.41 \%$ than the corresponding ones under SSDI, respectively. PRD technique with full irrigation (FI $\left.I_{P R D}\right)$ treatment increase the yield and WP by average values about $7.5 \%$ and $16.25 \%$ than that obtained without PRD, respectively under SDI and SSDI.

*Lecturer at Department of Agricultural and Bio-systems Engineering, Faculty of Agriculture, Benha University, Egypt. abousrie.ahmad@fagr.bu.edu.eg 
In addition, the PRD technique associated with deficit irrigation treatments resulted in lower fluctuation in the water contents in the vertical distribution than that obtained by the corresponding treatments without PRD technique. While, the using DI decreased the yield and increase WP by different percentage. DI $I_{75 \%}$ decrease the yield by average value $14.9 \%$ than that obtained at FI and increase WP by $29.1 \%$ under SDI and SSDI. $D I_{50 \%}$ significantly decreased the yield by average value $36.25 \%$ and increase significantly the WP by $59.1 \%$ than the corresponding values at FI. The statistical analysis showed that, there were no significant differences among the FI $I_{P R D}, F I$ and $D I_{75+P R D}$. The SDI resulted in increasing in yield by $4.11 \%$ but not significant than that obtained by SSDI, and SSDI increased WP by $7.15 \%$ than that achieved under the SDI, however the differences between these values were not significant.

Keywords: Hydrus-1D, sustainable deficit irrigation, soil water content, surface drip irrigation, subsurface drip irrigation and water productivity.

\section{INTRODUCTION}

s a result of steep population growth and limited water resources,
the food and water gaps in Egypt are growing rapidly (Abdelkader
et al., 2018). The agricultural sector consumes around $85 \%$ of the Nile water and this percentage is expected to increase due to the increased population and consequently the increased agricultural demands (FAO, 2018).

Improving the sustainability of irrigation systems requires optimizing operational parameters such as the threshold of irrigation and the amount of irrigation. Numerical modeling is a means of optimizing such operational parameters quickly and accurately (Dabash et al. ,2013). Using the numerical model data as a data source for modeling soil moisture is considered a good method for calculating the potential evapotranspiration and consequently the water requirement accurately from the output of a numerical atmospheric model (Dabash et al.,2013).

Many numerical methods have been used in soil to predict water flow and transportation processes. HYDRUS-1D is one of the recent models in this respect. This model was created and developed under different moisture 
conditions to simulate the movement of water, solutes and heat flow in porous media. This model describes water and solvent movement. (Simunek et al.,1998a and Noshadi and Torkaman, 2018).

Deficit irrigation means that the water applied is reduced to only a fraction of potential evapotranspiration of a well-watered reference crop $\left(\mathrm{ET}_{\mathrm{C}}\right)$. According to English and Raja (1996) deficit irrigation is an optimization strategy, under which crops are deliberately subjected to some degree of water deficit and reduced yield.

An irrigation-deficit strategy can be implemented in different ways, mainly differing in how the water limitation is applied. Sustainable deficit irrigation (DI) is based, in particular, on a uniform restriction of water, depending on the requirements of crop water. This approach makes it possible for the crop to adapt to the stressful situation. DI reduce the production of biomass under moderate water stress due to reduced canopy size and interception of radiation (Fereres and Soriano, 2006).

Determining accurate yield expectations under deficit irrigation conditions, corrects irrigation scheduling, and using current best management practices for nitrogen can help minimize leach nitrate losses Tarkalson et al., (2006).

Partial root-zone drying (PRD) is a new water-saving irrigation strategy which requires that the roots are simultaneously exposed to both dry and wet soil zones. This technique is now undergoing extensive trials with a range of agricultural crops. According to Jovanovic, et al., (2010), the PRD strategy could save $33 \%$ to $42 \%$ of irrigation water requirements while maintaining, at the same time, almost similar yields of potato.

Also, Topcu and et. al, (2007) found that, the highest yield of tomato was under full irrigation (FI), followed respectively by partial root drying (PRD) and deficit irrigation (DI). Water use efficiencies (WUE) were significantly higher for both PRD and DI compared to full irrigation. The PRD practices can be viable and advantageous in comparison with conventional techniques to minimize crop yield reductions during irrigation deficit. 
At the full bearing period, the eggplant was most sensitive to deficit irrigation, which not only restricted root growth and spatial distribution, but also reduced yield significantly ZhenYu et. al. (2010).

According to Karam et. al. (2011), in full irrigation, the average of soil water deficit $(S W D)$ was about 30 percent of total available water $(T A W)$, while in deficit irrigation it ranged from 50 to 75 percent of TAW. In response to deficit irrigation, the reduction in fresh yield of eggplant was compensated by an increase in the mean weight of the fruit. The fruit fresh yield in the control was $33.7 \mathrm{tha}^{-1}$, while it was 12,39 and 60 percent lower in 80,60 and 40 percent of DI.

The aim of this study are evaluate the simulation of soil water flow, root growth and root water uptake in clay soil for eggplant by HYDRUS-1D under both deficit irrigation (DI), partial root zone drying (PRD) and the integration between them and their effects on eggplant yield and water productivity (WP)

\section{MATERIALS AND METHODS}

\section{The experimental site.}

The experimental site was located at Faculty of Agriculture (Moshtohor), Benha University, in El-Qalubia governorate, Egypt. It placed at latitude $30^{0} 21^{\prime} 26.24^{\prime \prime}$, longitude $31^{0} 13^{\prime} 15.89^{\prime /}$ and $15 \mathrm{~m}$ above sea level and receives rainfall in winter at a rate of about $22 \mathrm{~mm} /$ year. The metrological data were recorded by iMatios station of Faculty of Moshtohor.

The soil of the experimental site was physically and chemically analyzed according to Holliday (1990) and Blume (1985). Results of analysis showed that this soil was of $\mathrm{pH} 7.77$ and EC $2.81 \mathrm{dS} \mathrm{m}^{-1}$. The soil textural class was clay; saturation percentage was $75.5 \%$; field capacity $(F C)$ was $36.28 \%$; permanent wilting point $(P W P)$ was $17.39 \%$; total available water was $(T A W) 18.93 \%$; bulk density was $1.15 \mathrm{Mg} \mathrm{m}^{-3}$; particle density was $2.2 \mathrm{Mg} \mathrm{m}^{-3}$ and total porosity was $47.74 \%$. The main properties of the irrigation water were $\mathrm{EC}$ of $2.65 \mathrm{dS} \mathrm{m}^{-1}$ and $\mathrm{pH}$ of 7.34.

The eggplant (soma sp.) was transplanted after 20 days of seeding during the summer seasons of 2017 and 2018 at distances of $50 \mathrm{~cm}$ between plants on each row and $80 \mathrm{~cm}$ between rows of $11.5 \mathrm{~m}$ length. The specification 
of the used drip irrigation system were GR laterals of $50 \mathrm{~cm}$ emitters spacing and $4 \mathrm{l} / \mathrm{hr}$ emitter flow rate at $0.8 \mathrm{bar}$. Two drip irrigation layouts were used; surface drip irrigation (SDI) and subsurface drip irrigation (SSDI). Different irrigation levels were studded: the full irrigation FI (100\% of ETc), DI $75 \%$ (deficit irrigation at $75 \%$ of ETc) and $\mathrm{DI}_{50 \%}$ (deficit irrigation at $50 \%$ of $E T c$ ). The PRD technique was applied under all treatments ( $\mathrm{FI}_{\mathrm{PRD}}, \mathrm{DI}_{75 \%+\mathrm{PRD}}$ and $\left.\mathrm{DI}_{50 \%+\mathrm{PRD}}\right)$ as shown in Fig. (1).

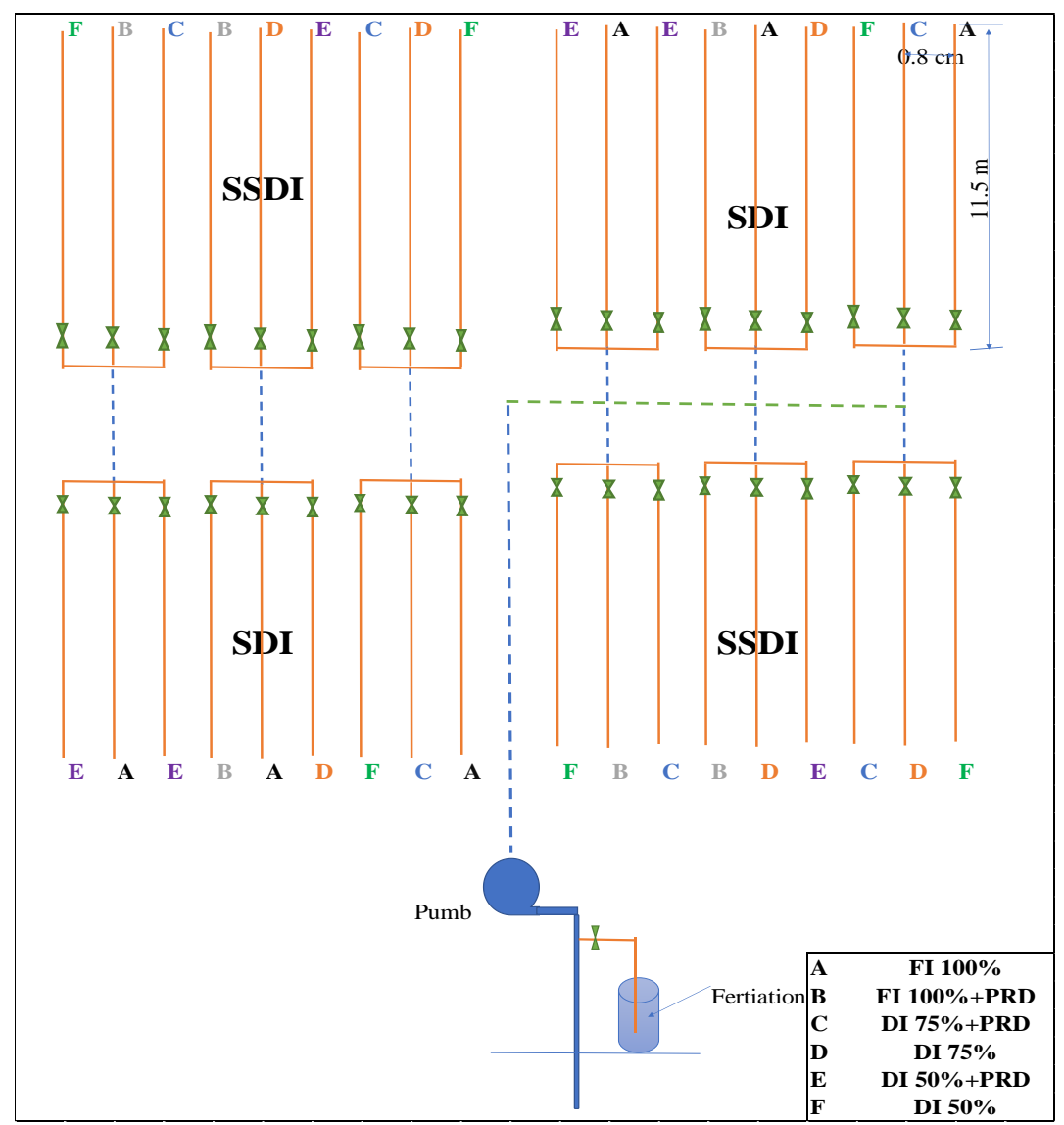

Figure (1): Irrigation management strategies under SDI and SSDI for eggplant crop.

To achieve the PRD treatments two drip irrigation lines for each treatment were at distance $60 \mathrm{~cm}$ from each other and the plant was located in the center between them. Each irrigation event only one of them was used for irrigation alternatively with the other one at the half period of irrigation intervals. 
The applied fertilizer requirements of eggplant were $250 \mathrm{~kg}$ nitrogen, 55 $\mathrm{kg} \mathrm{P}_{2} \mathrm{O}_{5}$ and $60 \mathrm{~kg} \mathrm{~K}_{2} \mathrm{O} \mathrm{ha}^{-1}$ according to FAO, 2005.

\section{Irrigation Water Requirement:}

The IRRMIT model integrated with iMatios station web site, which is supplied by many sensors was used for measuring humidity, temperature, radiation, perspiration, wind speed and wind direction. IRRMIT model used the recoded data of iMatios for calculating reference evapotranspiration and crop evapotranspiration according to BenmanMontith equation and FAO table, equation (1) (Allen et. al., 1998).

$$
E T c=E T o K_{C}
$$

where: $E T_{C}$ is the crop evapotranspiration in $\mathrm{mm} /$ day, $E T_{O}$ is the potential evapotranspiration in $\mathrm{mm} /$ day and, $K c$ is the single crop factor.

The total available water (TAW) was calculated as the difference between soil moisture content $(\theta)$ at field capacity $(F C)$ and the corresponding one at the permanent wilting point (PWP) multiplied by the root depth. The root depth was predicted according to Borg and Grimes (1986). Irrigation interval was equal to the radial available water $(R A W)$ divided by the summation of ETc of the period between each followed irrigation events, where $R A W$ is the fraction (p) of total available water, $(0.5$ of $T A W)$. The leaching requirement $(L R)$ was 0.2 of total applied irrigation depth and Irrigation water applied $\left(I_{W}\right)$ was calculated as:

$$
I_{W}=R A W / E i(1-L R)
$$

Where Ei is the irrigation efficiency, $90 \%$ for SDI and $95 \%$ for SSDI.

\section{Numerical model}

Soil water content $(\theta)$ values during the growth season were simulated by Hydrus-1D program. Three models i.e. hydraulic model, root water uptake and root growth were used for estimating the $\theta$ at different soil depths for eggplant crop during the growth seasons.

Van Genuchlen-Mualem model (Hydraulic model) was used for simulated the water flow in soil according to van Genuchten (1980) as shown in equation 5 for single porosity soil (the soil was of homo genius pores system) and no hysteresis with air entry value of $2 \mathrm{~cm}$ for subsurface drip irrigation system and without air under surface drip irrigation system. 
Three soil samples at depths of 0-20, 20-40 and 40-60 cm were laboratory mechanically analyzed (gradation analysis of soil test) for measuring the percentage of clay, silt and sand before the growth season according to ASTM, 2007 (D422), which are the input parameters of ROSETTA model to predict the empirical parameters of van Genuchten model as shown in Table (1).

Table (1). Soil gradation analysis and empirical parameters of Van Genuchlen-Mualem model at different soil depths predicted by ROSETTA model for clay soil

\begin{tabular}{|c|c|c|c|c|c|}
\hline \multirow[b]{2}{*}{ Parameters } & & & \multicolumn{3}{|c|}{ Soil depth } \\
\hline & & & $0-20 \mathrm{~cm}$ & $20-40 \mathrm{~cm}$ & $40-60 \mathrm{~cm}$ \\
\hline Soil particle & $e_{\text {Sond }}$ & Coarse & 20.95 & 21.23 & 18.30 \\
\hline & Sand & Fine & 1.28 & 1.96 & 2.62 \\
\hline distribution & Silt & & 27.92 & 28.19 & 31.16 \\
\hline$(\%)$ & Clay & & 49.85 & 48.62 & 47.92 \\
\hline$\overline{\theta_{r}}$ & & & 0.1019 & 0.1034 & 0.1054 \\
\hline$\theta_{S}$ & & & 0.529 & 0.5413 & 0.5593 \\
\hline$\alpha(1 / \mathrm{mm})$ & & & 0.00172 & 0.00187 & 0.00199 \\
\hline $\mathrm{n}$ & & & 1.3421 & 1.3326 & 1.3229 \\
\hline$K s$ (mm/day) & & & 338.5 & 419.8 & 526.1 \\
\hline$I$ & & & 0.5 & 0.5 & 0.5 \\
\hline
\end{tabular}

Where $\theta_{r}$ is the residual soil water content $\left(\mathrm{mm}^{3} \cdot \mathrm{mm}^{-3}\right), \theta_{S}$ is the saturated soil water content $\left(\mathrm{mm}^{3} \cdot \mathrm{mm}^{-3}\right)$, parameter $\alpha$ is the soil water retention function $\left(\mathrm{mm}^{-1}\right), \mathrm{n}$ is a parameter in the soil water retention function, $K s$ is the saturated hydraulic conductivity, $\left(\mathrm{mm} \mathrm{day}{ }^{-1}\right)$ and $I$ is tortuosity parameter in the conductivity function.

$\theta(h)=\mid \begin{array}{ll}\theta_{r}+\frac{\theta_{s}-\theta_{r}}{\left[1+|\alpha h|^{n}\right]^{m}} & h<0 \\ \theta_{s} & h \geq 0\end{array}$

Where : $\theta(h)$ the function of the soil water content $\left(\mathrm{mm}^{3} \cdot \mathrm{mm}^{-3}\right) h$ is airentry value $(\mathrm{mm}), \mathrm{m}=1-1 / \mathrm{n}$ is empirical parameter as shown in table (1).

The water flow boundary conditions were variable flux (irrigation depths) and free drainage at upper and lower boundaries, respectively and the initial condition was water content. 
Root water uptake model of Feddes and Zaradny (1978) was used for studying the values of water consumed by plant and the residual water in soil. The input data of Feddes model were: the pressure head below which roots start to extract water from the soil $(P O=-100 \mathrm{~mm})$, pressure head below which roots extract water at the maximum possible rate ( $P O p t=-250$ $\mathrm{mm})$, high potential transpiration rate $(\mathrm{r} 2 \mathrm{H}=5 \mathrm{~mm} /$ day), limiting pressure head below which roots can no longer extract water at the maximum rate at high potential transpiration rate $(r 2 \mathrm{H}) \mathrm{P} 2 \mathrm{H}=-8000 \mathrm{~mm}$, but for a low potential transpiration rate $(r 2 L)=1(\mathrm{~mm} /$ day $) P 2 L=-15000 \mathrm{~mm})$ and the pressure head below which root water uptake ceases $(P 3=-160000 \mathrm{~mm})$.

The root growth specified by using Verhulst-Pearl logistic (Growth Function). It is used to describe root growth during the growing season. The parameters were: initial root growth time as 30 days, the harvest time (160 days), the initial rooting depth $(100 \mathrm{~mm})$, the maximum rooting depth as $600 \mathrm{~mm}$ and the time period 130 days. The root growth factor was calculated by using the assumption that, $50 \%$ of the rooting depth is reached at the midpoint of the growing season. The root water uptake is calculated by using the root growth model as following according to Hoffman and Van Genuchten, 1983 equation (6):

$$
b(x)=\left\{\begin{array}{lr}
\frac{1.66667}{L_{R}} & x>L-0.2 L_{R} \\
\frac{2.0833}{L_{R}}\left(1-\frac{X_{0}-X}{L_{R}}\right) & X \in\left(L-L_{R} ; L-0.2 L_{R}\right) \\
0 & X<L-L_{R}
\end{array}\right.
$$

where $\mathrm{b}(\mathrm{x})$ is the normalized water uptake distribution at depth $\mathrm{x}\left(\mathrm{mm}^{-1}\right)$, $L$ is the x-coordinate of the soil surface $(\mathrm{mm})$ and $L_{R}$ is the root depth (mm).

The daily meteorological data are the other inputs for both models. The meteorological data were used to calculate the Potential ET.

\section{Estimating and predicting of soil water content, $\theta$}

Soil water content $(\theta)$ was measured by Delta ML3 Theta Probe soil moisture sensor several times during the growing season to compare 
between the measured values and the corresponding ones simulated and predicted by Hydrus-1D under all treatments as shown in Fig. (2).

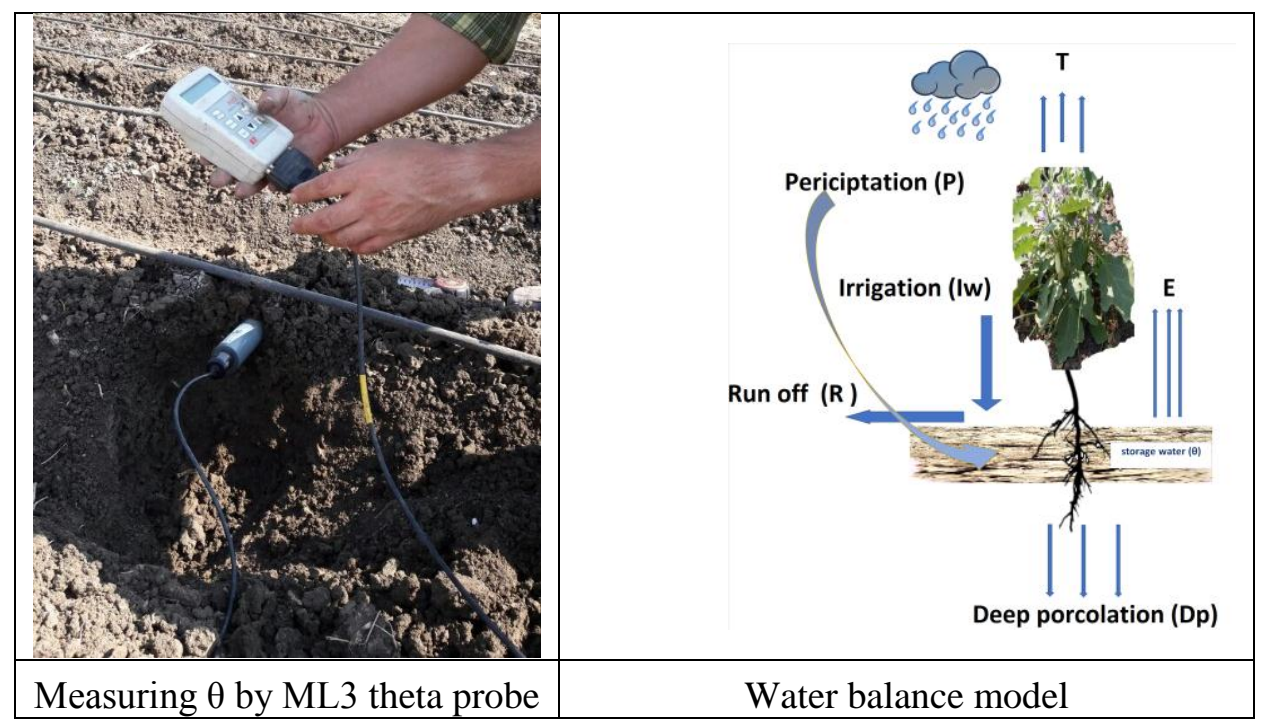

Fig. (2). Measured and predict soil water content

The predicted soil water content can be estimated by water balance equation (3) as shown in fig. (2).

$$
P+I_{w}=E T c+R+D P-\triangle W
$$

where, $\mathrm{P}$ is the precipitation $(\mathrm{mm}), I_{w}$ is the applied irrigation depth $(\mathrm{mm})$, $R$ is the run off (mm) it was neglected for SDI and SSDI , $D p$ is the deep percolation (drainage water) $(\mathrm{mm})$ and $\Delta W$ is the change in soil water content or soil depletion $(\mathrm{mm})$ as:

$$
\Delta W=\theta_{i}-\theta_{i+n}
$$

where, $\theta_{i}$ is the soil water content after irrigation and $\theta_{i+n}$ soil water content before irrigation or at the end of the irrigation interval.

\section{Yield and water productivity, (WP).}

Eggplant was harvested at mid stage twice per weak for period of 30 days. The total yield for each treatment was measured for each line. Water productivity (WP) is defined, according to Molden et al. (2010), as the net benefit from the crop to the amount of water used to produce those benefits, i.e., the relationship between the marketable fruit yield $\left(\mathrm{kg} \mathrm{ha}^{-1}\right)$ and the total water applied $\left(\mathrm{m}^{3} \mathrm{ha}^{-1}\right)$ (Patanè et al., 2011). 


\section{Statistical analysis}

The experimental design was randomized complete block design (RCBD) with 3 replicates fig. (1). The results of yield and WP were analyzed statistically by using ANOVA and Tukey HSD test with two factors at $\mathrm{p}=$ 0.05 .

\section{RESULTS AND DISCUSSIONS}

\section{The measured and modeled values of soil water content $(\theta)$.}

The $\theta\left(\mathrm{cm}^{3} \mathrm{~cm}^{-3}\right)$ values were obtained at different soil depths 10, 30 and $50 \mathrm{~cm}$ for different irrigation management strategies (FI, $\mathrm{DI}_{75 \%}, \mathrm{DI}_{50 \%}$, FI $I_{\text {PRD }}, \mathrm{DI}_{75 \%+\mathrm{PRD}}$ and $\mathrm{DI}_{50 \%+\mathrm{PRD}}$ ) under SDI and SSDI. The predicted values of $\theta$ by HYDRUS-1D model were very close to the measured values at all treatments under SDI and SSDI as shown in Fig. (3, 4, 5, 6, 7 and 8).

The highest average value of $\theta$ was $0.31\left(\mathrm{~cm}^{3} \mathrm{~cm}^{-3}\right)$ at both FI and FIPRD followed by $\mathrm{DI}_{75 \%+\mathrm{PRD}}\left(0.27 \mathrm{~cm}^{3} \mathrm{~cm}^{-3}\right)$ and $\mathrm{DI}_{75 \%}\left(0.26 \mathrm{~cm}^{3} \mathrm{~cm}^{-3}\right)$ and the lowest mean value of $\theta$ was $0.25\left(\mathrm{~cm}^{3} \mathrm{~cm}^{-3}\right)$ at $\mathrm{DI}_{50 \%+\mathrm{PRD}}$ and $\mathrm{DI}_{50 \%}$ during the growth season.

The mean value of $\theta$ at a depth $10 \mathrm{~cm}$ during the growth season under SSDI was $0.3\left(\mathrm{~cm}^{3} \mathrm{~cm}^{-3}\right)$ higher than the corresponding one under SDI $\left(0.26 \mathrm{~cm}^{3}\right.$ $\left.\mathrm{cm}^{-3}\right)$. This finding was regardless of the irrigation treatment whether it was FI, FI $I_{P R D}, \mathrm{DI}_{75} \%, \mathrm{DI}_{75 \%+\mathrm{PRD}}, \mathrm{DI}_{50 \%}$ or $\mathrm{DI}_{50 \%+\mathrm{PRD}}$ as shown in Fig. $(3,4,5,6$, 7 and 8). This occurred because the applied irrigation water under SSDI was at a depth of $10 \mathrm{~cm}$ which is the depth of lateral irrigation lines. On the other hand, the mean values of $\theta$ at depths of 30 and $50 \mathrm{~cm}$ were 0.27 and $0.3\left(\mathrm{~cm}^{3} \mathrm{~cm}^{-3}\right)$, respectively under SDI higher than the corresponding one under SSDI $\left(0.25\left(\mathrm{~cm}^{3} \mathrm{~cm}^{-3}\right)\right.$ at $30 \mathrm{~cm}$ and $0.27\left(\mathrm{~cm}^{3} \mathrm{~cm}^{-3}\right)$ at $\left.50 \mathrm{~cm}\right)$ as shown in Fig. (3, 4, 5, 6, 7 and 8).

Figures (3-a) and (3-b) show the changes in simulated and measured soil water content $(\theta)$ at depths 10,30 and $50 \mathrm{~cm}$ at FI treatment under SDI and SSDI during the growth season.

The results shown that, the changes in soil water content $(\theta)$ at depths 10 , 30 and $50 \mathrm{~cm}$ were located above the $R A W$ line under SDI, but under SSDI some few values were located under $R A W$ line by small distance. 

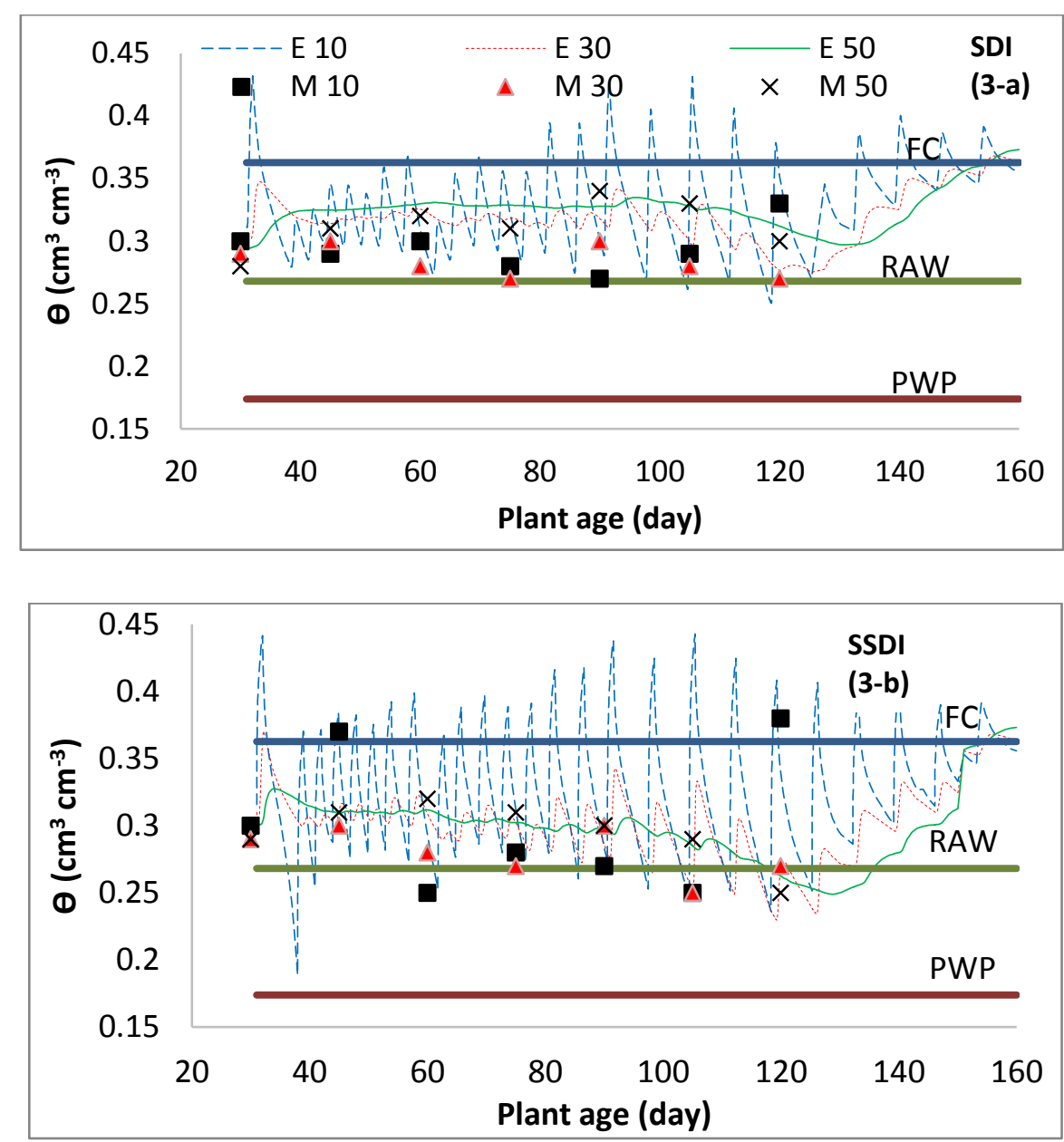

Fig. (3-a and 3-b). The simulated and measured soil water content $(\theta)$ under SDI and SSDI, respectively at FI during the growth season.

where E10, E30 and E50 are the simulated values of $\theta$ and M10, M30 and M 50 are the measured values of $\theta$ at depths 10,30 and $50 \mathrm{~cm}$, respectively. Figures (4-a) and (4-b) shows the results of the changes in simulated and measured values of soil water content $(\theta)$ at depths 10,30 and $50 \mathrm{~cm}$ at FIPRD treatment under SDI and SSDI, respectively.

The results shown the values of $\theta$ at depths 10,30 and $50 \mathrm{~cm}$ were located above the $R A W$ line, the mean value of $\theta$ at depth $10 \mathrm{~cm}$ under SSDI was $0.33\left(\mathrm{~cm}^{3} \mathrm{~cm}^{-3}\right)$ higher than that under SDI by about $5.4 \%$ than that under SDI during the growth season. At depth $30 \mathrm{~cm}$, the mean values of $\theta$ decreased by $6.06 \%$ under both SDI and SSDI, while at depth $50 \mathrm{~cm}$ it 
decreased by $3.03 \%$ and $12.12 \%$ under SDI and SSDI, respectively. The change in soil water content $\theta$ under SSDI was faster and more slope than SDI.

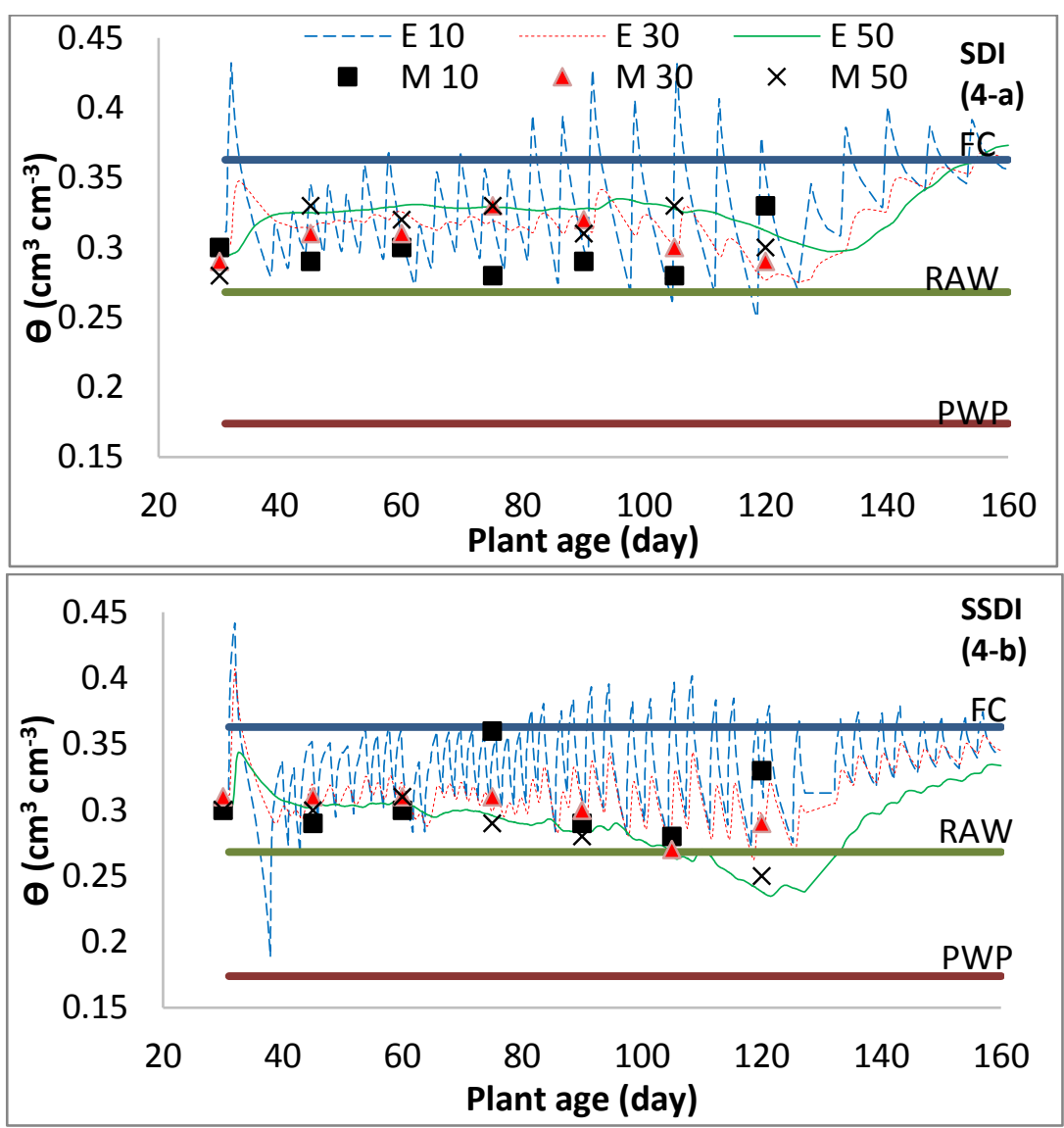

Fig. (4-a and 4-b). The predicted and measured soil water content $(\theta)$

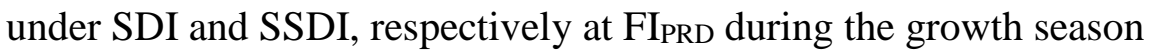

The results of simulated and measured $\theta$ at $\mathrm{DI}_{75 \%}$ during the growth season of eggplant at depths 10,30 and $50 \mathrm{~cm}$ are showing in figures (5-a) and (5b) under SDI and SSDI, respectively.

The changes in $\theta$ under SDI were changed rapidly than that under SSDI. The decreasing of water by $0.25 \%$ of ETc at $\mathrm{DI}_{75 \%}$ than FI cases decreasing the mean soil water content by $8.8 \%$ and $19.35 \%$ at $10 \mathrm{~cm}$ under SSDI and SDI, respectively, while at soil depth $30 \mathrm{~cm}$ it was $20.7 \%$ and 19.35 $\%$ under SSDI and SDI, respectively. At soil depth $50 \mathrm{~cm}$ the decrease in $\theta$ 
than FI were $16.7 \%$ and $9.4 \%$ under SSDI and SDI, respectively. The soil water content values distrusted up and down $R A W$.

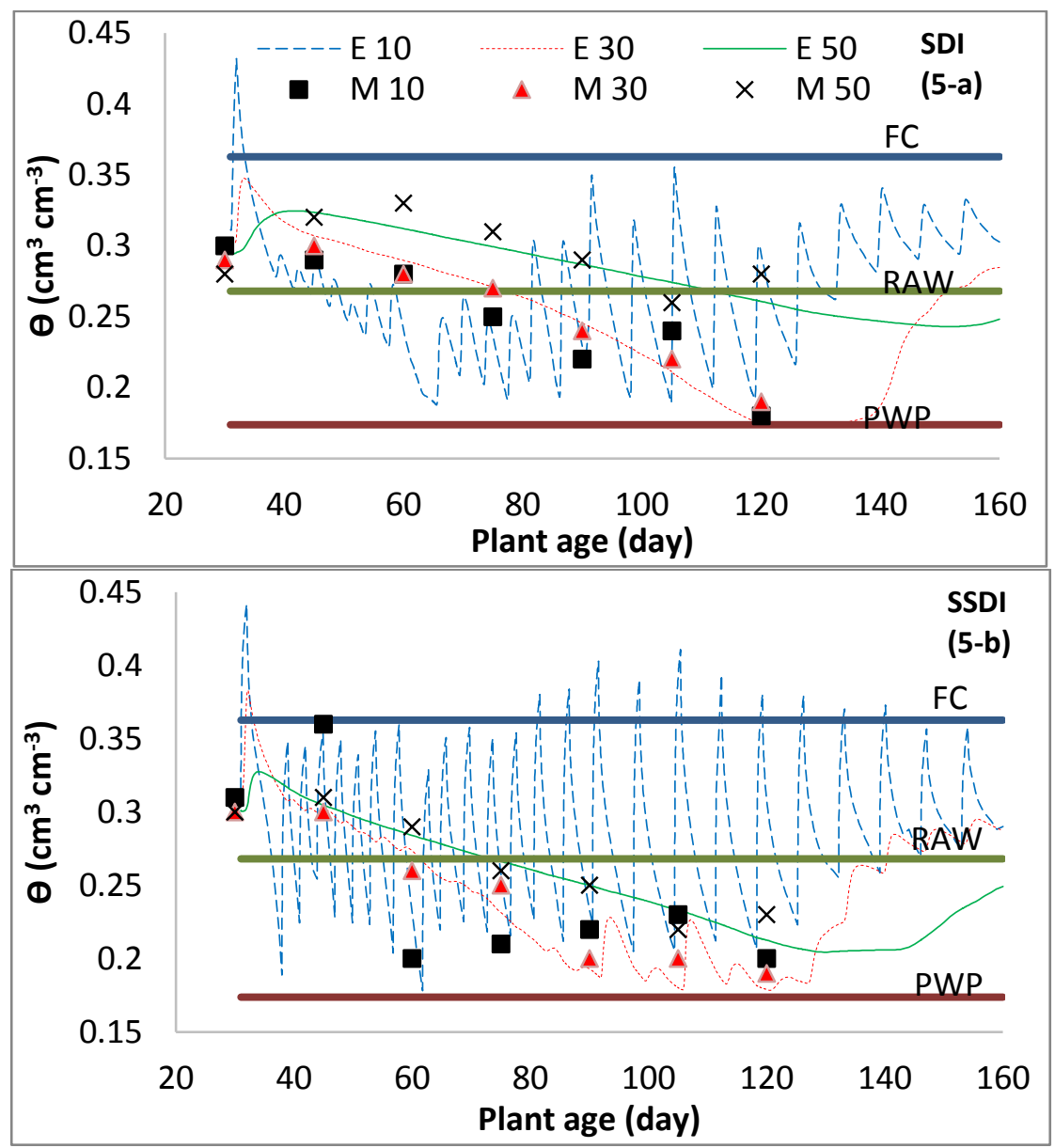

Fig. (5-a and 5-b). The simulated and measured soil water content $(\theta)$ under SDI and SSDI, respectively.at $\mathrm{DI}_{75} \%$ during the growth season.

Figures (6-a) and (6-b) show the $\theta$ values under SDI and SSDI, respectively at depths $10 \mathrm{~cm}, 30 \mathrm{~cm}$ and $50 \mathrm{~cm}$ during the growth season at $\mathrm{DI}_{75 \%+\mathrm{PRD}}$ treatment.

The results of integration between $\mathrm{DI}_{75 \%}$ and $\mathrm{PRD}$ in treatment $\mathrm{DI}_{75 \%+\mathrm{PRD}}$ didn't case any change in mean value $\theta$ at different depth under SDI and SSDI, but it improved from the distribution of soil water content around $R A W$ at depth $10 \mathrm{~cm}$ only. Also, PRD at depth $10 \mathrm{~cm}$ raise $\theta$ values above $R A W$. 

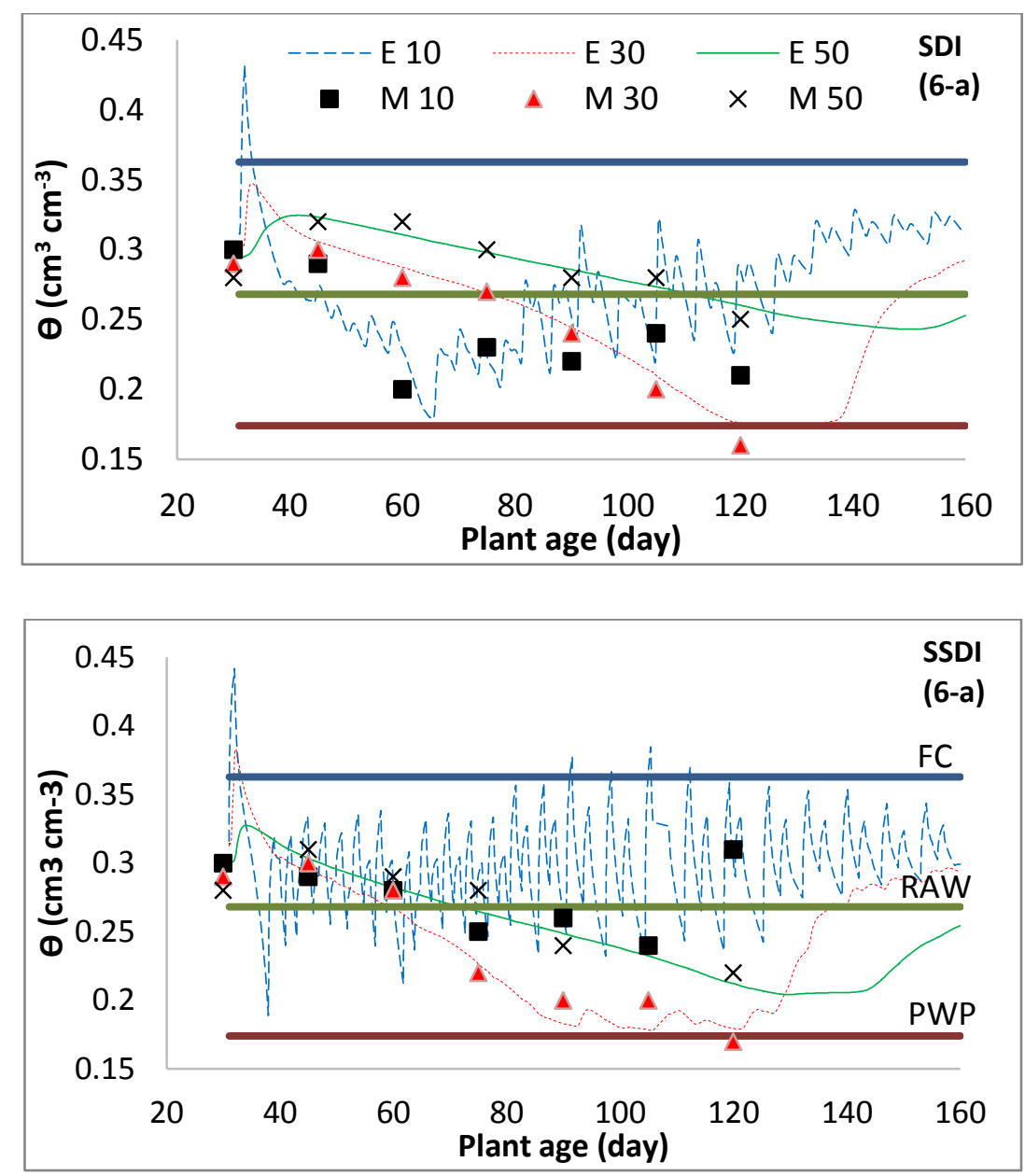

Fig. (6-a and 6-b) The simulated and measured soil water content $(\theta)$ under SDI and SSDI, respectively at $\mathrm{DI}_{75 \%+\mathrm{PRD}}$ during the growth season. Figures (7-a) and (7-b) show the $\theta$ values under SDI and SSDI, respectively at depths $10 \mathrm{~cm}, 30 \mathrm{~cm}$ and $50 \mathrm{~cm}$ during the growth season at $\mathrm{DI}_{50 \%}$ treatment.

Decreasing water flux (irrigation water) into soil by 50\% than ETc make decrease in soil water content $\theta$ values at depth $10 \mathrm{~cm}$ by $35.7 \%$ and 21.5 $\%$, while at depth $30 \mathrm{~cm}$ were $20.2 \%$ and $23.2 \%$ and at depth $50 \mathrm{~cm}$ were $10.5 \%$ and $15.7 \%$ under SDI and SSDI, respectively.

Figures (8-a) and (8-b) show the $\theta$ values under SDI and SSDI, respectively at depths $10 \mathrm{~cm}, 30 \mathrm{~cm}$ and $50 \mathrm{~cm}$ during the growth season at $\mathrm{DI}_{50 \%+\mathrm{PRD}}$ treatment. 

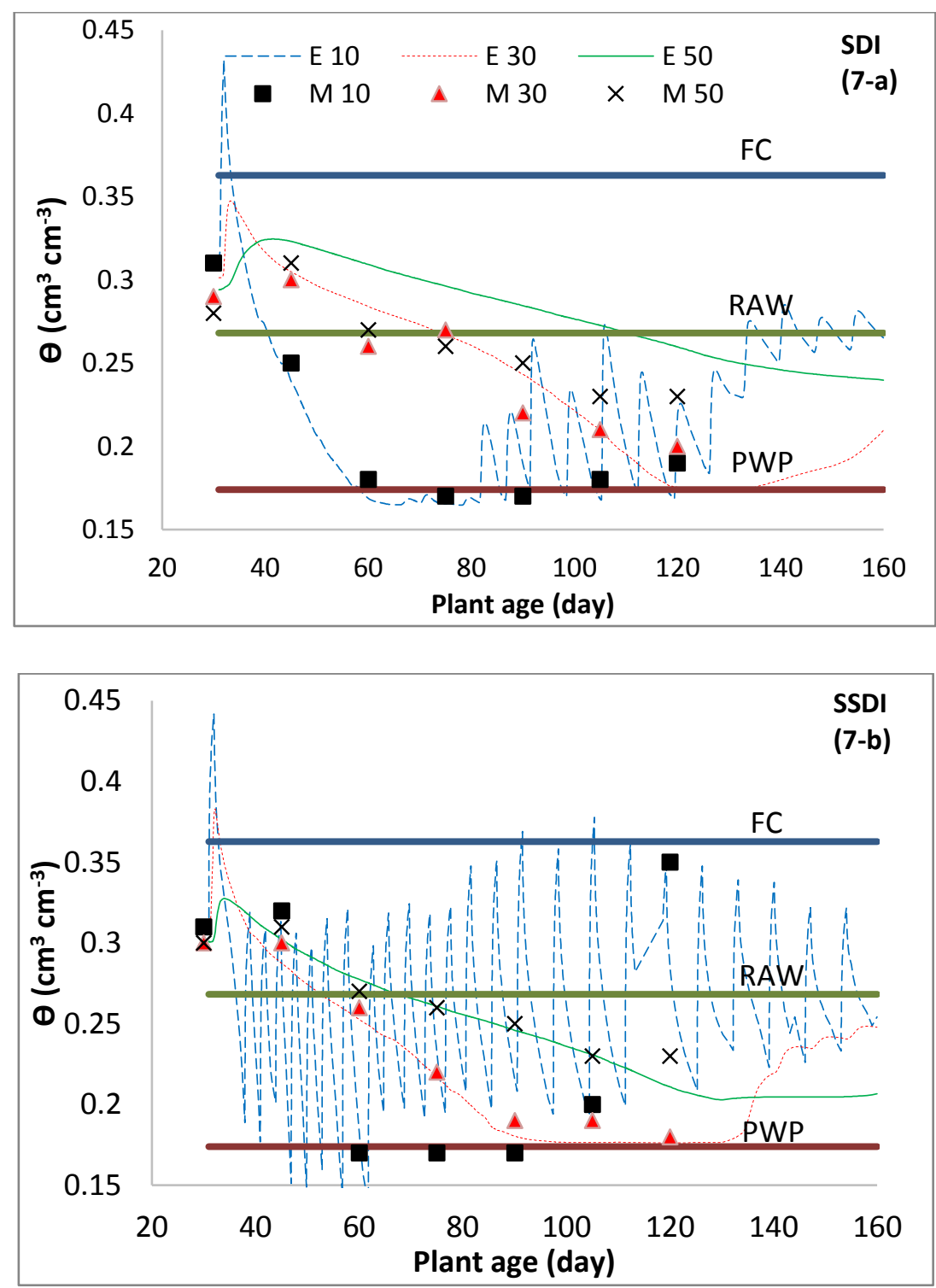

Fig. (7-a and 7-b). The predicted and measured soil water content $(\theta)$ under SDI and SSDI, respectively at $\mathrm{DI}_{50 \%}$ during the growth season.

The results shown that, interaction between $\mathrm{DI}_{50 \%}$ and PRD case increase in soil water content $(\theta)$ at soil depth $10 \mathrm{~cm}$ by $5 \%$ and $3.7 \%$, while at depth $30 \mathrm{~cm} \theta$ decreased by $1.6 \%$ and $1.2 \%$ under SDI and SSDI, respectively and at soil depth $50 \mathrm{~cm} \theta$ decreased by $1.2 \%$ under SDI and increased by $0.5 \%$ under SSDI. 

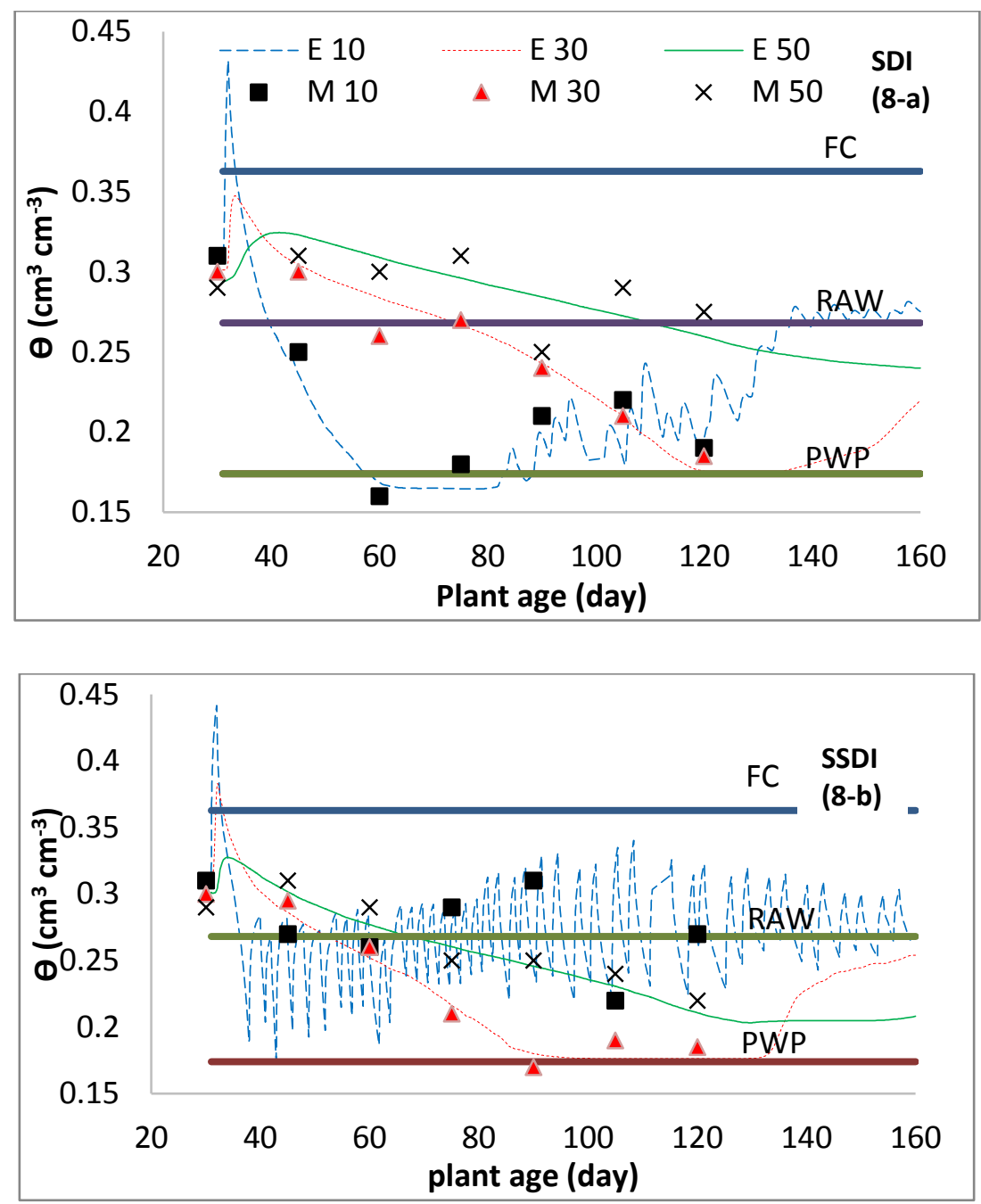

Fig. (8-a and 8-b). The predicted and measured soil water content $(\theta)$ under SDI and SSDI, respectively at DI $50 \%+$ PRD during the growth season.

PRD decreased the water stress by saving $\theta$ above $P W P$ compared with that without PRD. Also, PRD make good distribution for soil water near $R A W$ than that without it. The almost values were located above the $P W P$ line except some simulated and measured values at depth $10 \mathrm{~cm}$ under SDI and one measured value at depth $30 \mathrm{~cm}$ under SSDI but it was very close to $P W P$. 
The effects of soil water content $(\theta)$ on yield and water productivity, WP The results in Figure (9) illustrated the values of eggplant yield in both cultivation seasons 2017 and 2018 at FIPRD, FI, DI $75 \%$, DI $75 \%+$ PRD, DI50\% and $\mathrm{DI}_{50 \%+\mathrm{PRD}}$ irrigation treatments under SDI and SSDI systems.

SDI achieve increase but not significant in yield by $3.9 \%$ than SSDI, duo to the increase of soil content under SDI than that under SSDI as shown in figures $(3,4,5,6,7$, and 8$)$. PRD technique gave increase in yield by about $7.5 \%$ at FIPRD more than FI duo to the good distribution of soil water content than the corresponding values without PRD as shown in figures (3, $4,5,6,7$ and 8).

DI archived decreased in yield ranged from $14.9 \%$ at $\mathrm{DI}_{75 \%}$ and $36.3 \%$ at $\mathrm{DI}_{50 \%}$. Also, the results shown the integration between DI and PRD gave increase in yield by about $9.6,7.5$ and $6.3 \%$ at DI50\%+PRD, FIPRD and $\mathrm{DI}_{75 \%+\mathrm{PRD}}$, respectively than the corresponding treatments without PRD.

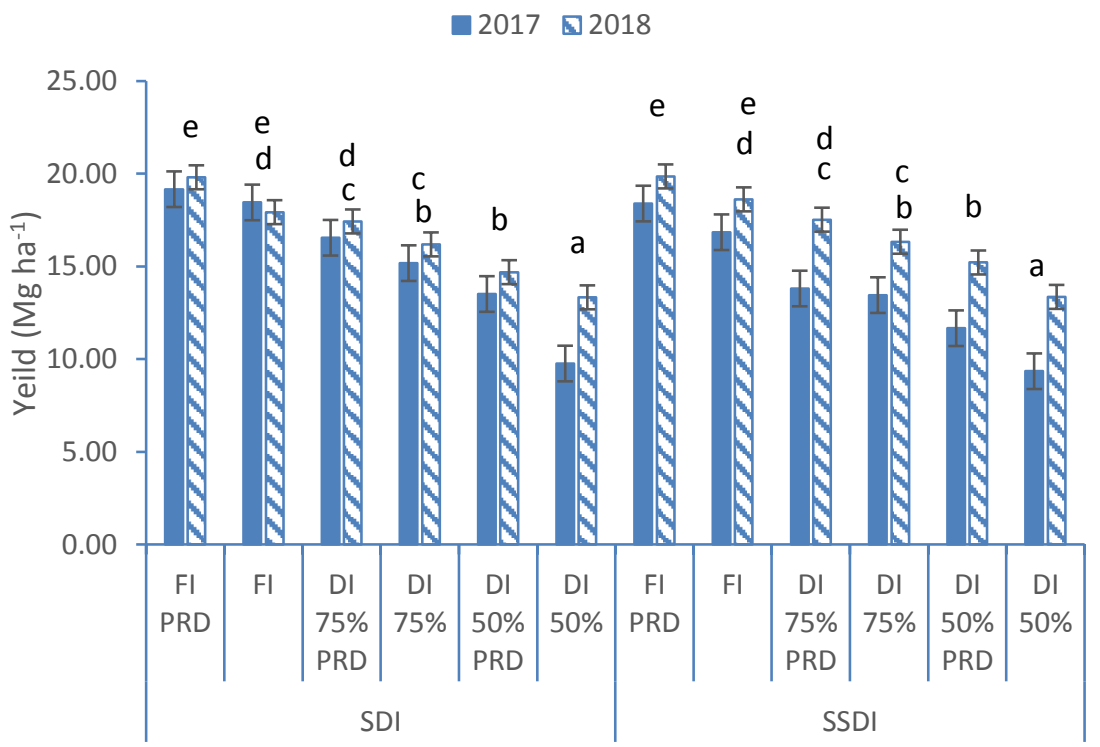

Fig. (9). The yields of eggplant at different irrigation strategies under SDI and SSDi.

A nova and Tukey HSD test show the differences among the irrigation treatments as shown in fig. (9), where a, b, c, d and e are show the significant differences between groups. Where the similar letters above the treatment, mean that there weren't any significant differences between that 
groups or treatments. On the other hand, $\mathrm{DI}_{50 \%}$ significantly decreased the yield than all other treatments. Integration PRD with DI increase the yield and make the differences between PRD treatments and upper treatments not significant as shown in fig. (9).

Fig. (10) illustrated the average values of WP during the growth seasons of 2017 and 2018. The results shown that, SSDI system resulted in higher values of WP of eggplant than the corresponding ones obtained under the SDI system by about $6.7 \%$, however, the differences in values between the two systems were not significant where $\mathrm{p}=0.083$ although SSDI consumed a lower quantity of irrigation water than the surface drip irrigation by $5 \%$. The PRD achieved increase in WP ranged from $74.5 \%$ at $\mathrm{DI}_{50 \%+\mathrm{PRD}}$ and $16.3 \%$ at FIPRD. The statistical analysis showed that, there were significant differences among FI and DI $_{50 \%}$ where p.value $=0.037$, high significant between FI and DI $50 \%+$ PRD where p.value $=0.005$ and FI $_{\text {PRD }}$ and $\mathrm{DI}_{50 \%+\mathrm{PRD}}$ where $\mathrm{p}$.value $=0.021$ at $\mathrm{p}=0.05$.

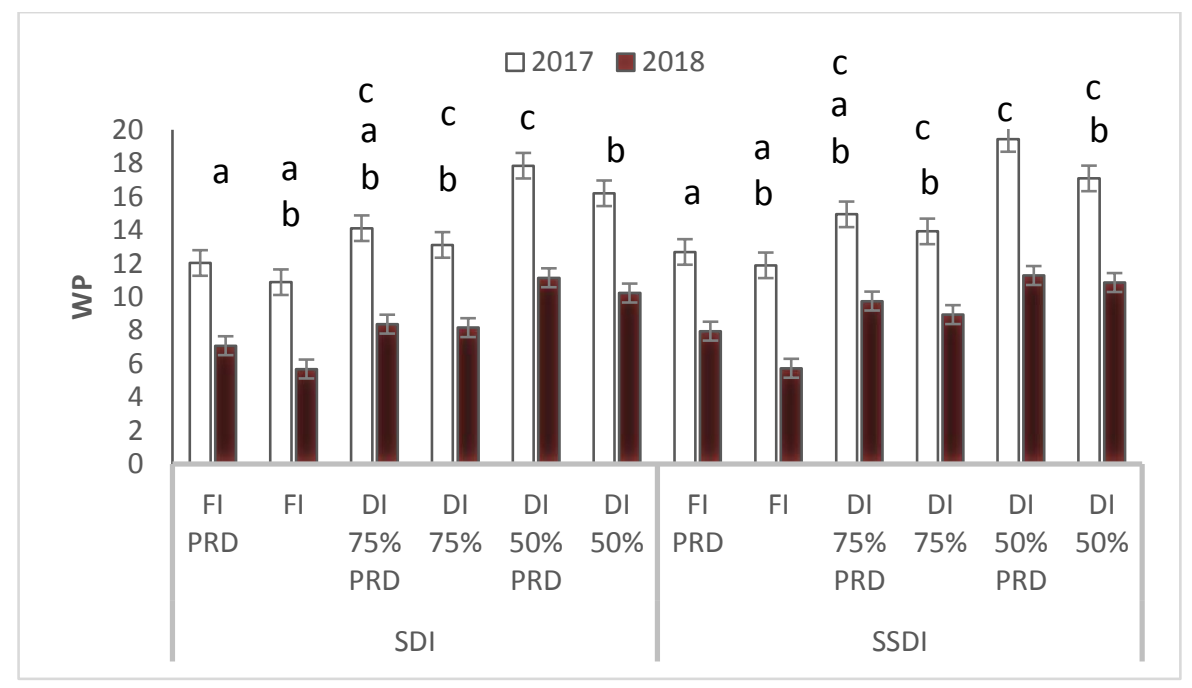

Fig. (10). Water productivity (WP) at different irrigation management strategies of eggplant under SDI and SSDI.

\section{CONCLUSION}

The results of numerical modeling for water flux in soil under deficit and partial root zone drying showed that, the modeled values by Hydrus-1D were very close to the measured values. 
The SDI increase yield by about $3.6 \%$ than SSDI, but not significant, because the mean values of soil water content under SDI was higher than that under SSDI. SSDI gave increase in values of water productivity (WP) by $6.7 \%$ higher but not significant than that obtained by SDI.

Applying of deficit irrigation integrated with partial root-zone drying improved the obtained yield, soil moisture contents and WP where the $\mathrm{DI}_{75 \%+\mathrm{PRD}}$ gave lower values of yield but not differed significantly from the corresponding ones achieved due to FI and FIPRD. So, we recommend integration between the sustainable deficit irrigation and partial root zone drying for saving water without significant loss of yield and also, we recommend the using Hydrus-1D for predicting the change in soil water content as cheap, fast and accurate method.

\section{ACKNOWLEDGMENT}

The author thanks ASRT for supporting this study, which was carried out within the project titled "Water Saving in Agriculture: Technological Developments for the Sustainable water Management of Limited Water Resources in the Mediterranean Area".

\section{REFERENCES}

Abdelkader, A., Elshorbagy, A., Tuninetti, M., Laio, F., Ridolfi, L., Fahmy, H. and Hoekstra, A. Y. (2018). National water, food, and trade modeling framework: The case of Egypt. Sci Total Environ, 639, 485-496. https://doi.org/10.1016/j.scitotenv.2018.05.197

Allen, R.G., Pereira L.S., Raes, D.and Smith, M., (1998). Crop evapotranspiration: guidelines for computing crop water requirements. FAO Irrigation and drainage paper N.O 56. Rome (Italy).

ASTM (2007). Standard Test Method for Particle-Size Analysis of Soils, ASTM International, West Conshohocken, PA, 2007. https://doi.10.1520/D0422-63R07E02

Blume, H.-P. (1985). Page, A. L., R. H. Miller and D. R. Keeney (Ed., 1982): Methods of soil analysis; 2 . Chemical and microbiological properties, 2. Aufl. 1184 S., American Soc. of Agronomy (Publ.), Madison, Wisconsin, USA, gebunden 36 Dollar. 148(3), 363-364. doi:10.1002/jpln.19851480319 
Borg, H., and D.W. Grimes. (1986) Depth development of roots with time: An empirical description. Trans. ASAE 29,194-197

Dabach, S., Lazarovitch, N., Šimůnek, J., \& Shani, U. J. I. S. (2013). Numerical investigation of irrigation scheduling based on soil water status. 31(1), 27-36. doi:10.1007/s00271-011-0289-x

Ehlers, W. (1984). Taylor, H. M., W. R. Jordan, T. R. Sinclair (Hrsgb.): Limitations to Efficient Water Use in Crop Production. American Society of Agronomy, Crop Science Society of America, Soil Science Society of America. Madison, Wisconsin, USA 1983. 538 Seiten. Kartoniert. US \$30. ISBN: 0-89118-074-5. 147(5), 645646. doi:10.1002/jpln.19841470526

English, M., and Raja, S. N. (1996). Perspectives on deficit irrigation. Agricultural Water Management, 32(1), 1-14. doi:https://doi.org/10.1016/S0378-3774(96)01255-3

FAO (2018). AQUASTAT. Retrieved 3 12, 2018, from http://www.fao.org/NR/WATER/AQUASTAT/main/index.stm

FAO (2005). Fertilizer use by crop in Egypt. Rome, Italy.

Feddes, R. A. and Zaradny, H. (1978). Model for simulating soil-water content considering evapotranspiration- Comments. Journal of Hydrology, 37(3), 393-397. doi:https://doi.org/10.1016/00221694(78)90030-6

Fereres, E., and Soriano, M. A. (2006). Deficit irrigation for reducing agricultural water use. Journal of Experimental Botany, 58(2), 147159. doi: $10.1093 / \mathrm{jxb} / \mathrm{erl} 165 \% \mathrm{~J}$ Journal of Experimental Botany

Hoffman, G. J., and Van Genuchten, M. (1983). Soil properties and efficient water use: Water management for salinity control. In (pp. 73-85).

Holliday, V. T. (1990). Methods of soil analysis, part 1, physical and mineralogical methods (2nd edition), A. Klute, Ed., 1986, American Society of Agronomy, Agronomy Monographs 9(1), Madison, Wisconsin, 1188 pp., $\$ 60.00$. 5(1), 87-89. doi:10.1002/gea.3340050110

Jovanovic, Z., Stikic, R., Vucelic-Radovic, B., Paukovic, M., Brocic, Z., Matovic, G., Rovcanin, S. and Mojevic, M., (2010). Partial root- 
zone drying increases WUE, $\mathrm{N}$ and antioxidant content in field potatoes. Eur. J. Agron. 33, 124-131, http://dx.doi.org/10.1016/j.eja.2010.04.003

Karam, F., Saliba, R., Skaf, S., Breidy, J., Rouphael, Y., and Balendonck, J. (2011). Yield and water use of eggplants (Solanum melongena L.) under full and deficit irrigation regimes. Agricultural Water Management, 98(8), 1307-1316. doi:https://doi.org/10.1016/j.agwat.2011.03.012

Molden D, Oweis T, Steduto P, Bindraban P, Hanjra MA and Kijne J (2010). Improving agricultural water productivity: Between optimism and caution. Agric Water Manage 97: 528-535.

Noshadi, M., and Torkaman, P. (2018). Analysis of 2,4-D residues in soil profile using HYDRUS-1D model \%J Iran Agricultural Research. 37(1), 31-40. doi:10.22099/iar.2018.4688

Patanè, C., Tringali, S. and Sortino, O. (2011). Effects of deficit irrigation on bio-mass, yield, water productivity and fruit quality of processing tomato under semi-arid Mediterranean climate conditions. Sci Hortic 129: 590-596.

Šimůnek, J., R. Angulo-Jaramillo, M.G. Schaap, J.-P. Vandervaere, and M.Th . van Genuchten. (1998a). Using an inverse method to estimate the hydraulic properties of crusted soils from tension disc infiltrometer data. Geoderma 86:61-81.

Tarkalson, D. D., Payero, J. O., Ensley, S. M., and Shapiro, C. A. (2006). Nitrate accumulation and movement under deficit irrigation in soil receiving cattle manure and commercial fertilizer. Agricultural Water Management, 85(1), 201-210. doi:https://doi.org/10.1016/j.agwat.2006.04.005

Topcu, S., Kirda, C., Dasgan, H., Kaman, H., Cetin, M., Yazici, A., \& Bacon, M. A. (2007). Yield response and $N$-fertiliser recovery of tomato grown under deficit irrigation (Vol. 26).

ZhenYu, Y., FuCang, Z., and Zhi-rong, Z. (2010). Coupling effects of deficit irrigation (DI) in different growth stages and different nitrogen applications on the root growth,yield,WUE of eggplant. Journal of Northwest A\&F University, 38(7), 141-148. 


\section{الملخص العربي \\ النمذجة العددية لحركة مياه التربة تحت الري الرئ الناقص التصن

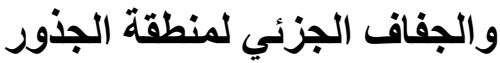

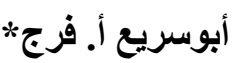

تعتبر الإدارة المائية الناجحة واحدة من اهم الحلول لمشكلة نقص المياه. واهم عو امل نجاحها هي

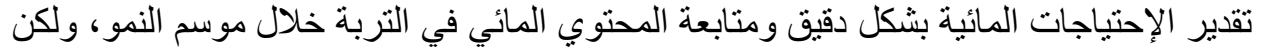

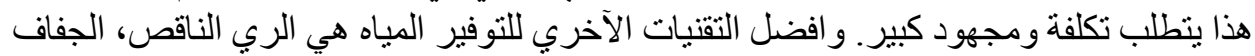
الجزئي لمنطقة الجذور. لذا تهدف هذه الدراسة الي محاكات سريان المياه في التربة في الإتجاه

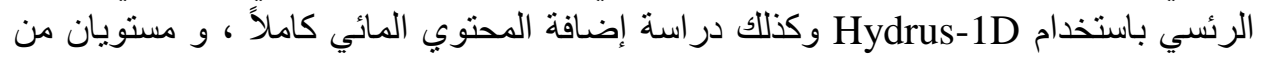

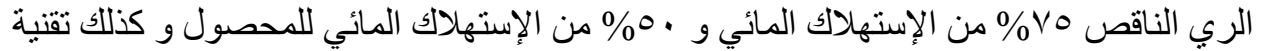
الجفاف الجزئي لمنطقة الجذور ايضا التكامل بين التقنيتان معا وتأثير هم علي الإنتاج و الإنتانية الإنتاجية

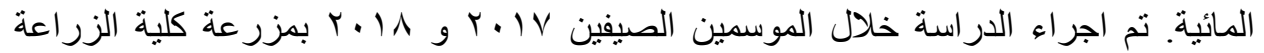
(بمشتهر)، جامعة بنها. حيث تم قياس المحتوي الرطوبي للتربة مرات ات عديدة خلال موسم النمو

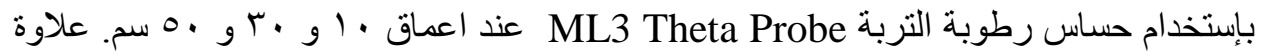
علي ذلك، تم استخدام النمذجة العددية لتوقع المحتوي الرطوبي للتربة ولة و مقارنة مخرجات المديل

مع القيم المقاسة الحقيقية. بينت نتائج التحليل العددي ان القيم الناتجة عن الموديل وكذلك القيم المقاسة كانت متشابه بشكل

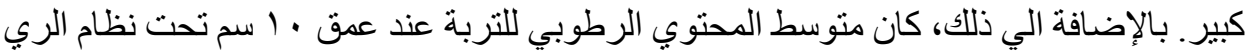

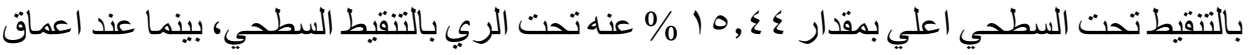

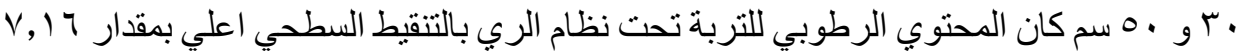

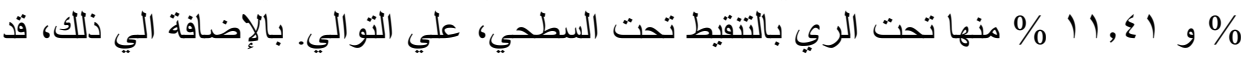

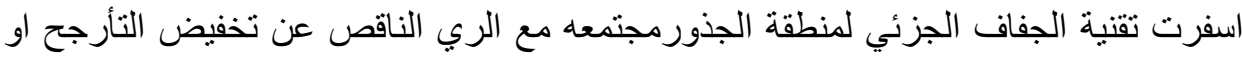

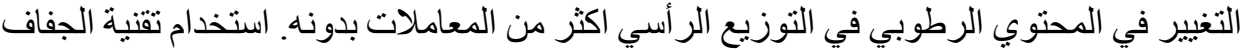

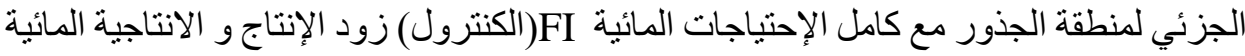

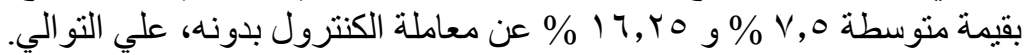

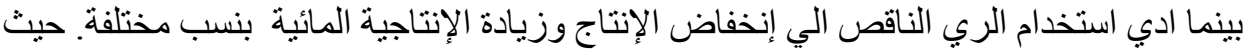

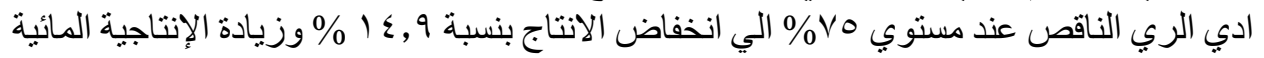

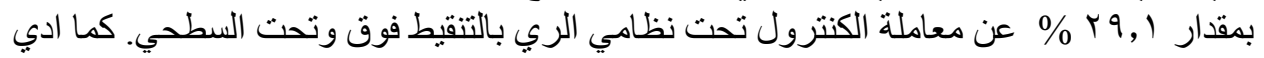

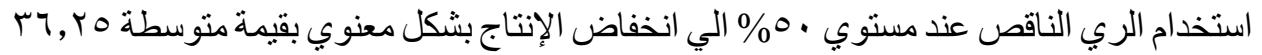

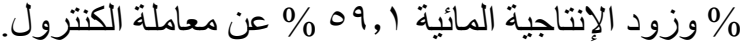
اوضح التحليل الاحصائي، عدم وجود اختلافات معنوية بين معاملة الري الرية الكامل ، و والري الري الكامل

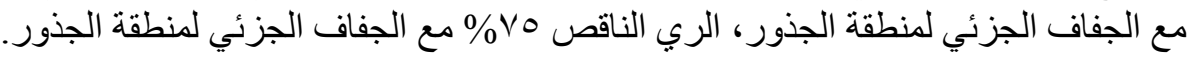

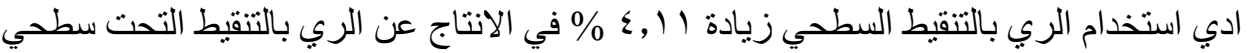

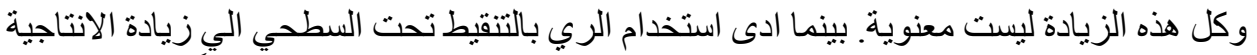

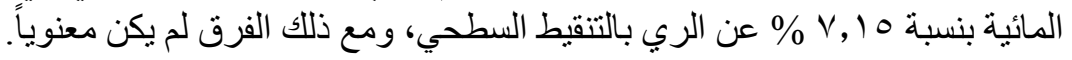

*مدرس بقسم هندسة النظم الزراعية و الحيوية ـ كلية الزراعة بمشتهر - جامعة بنها 